\title{
Polymorphisms of the MTHFR Gene in Mothers of Children with Trisomy 21 (Down Syndrome) in a Polish Population
}

\section{Paulina Czechowicz ( $\square$ paulina.czechowicz.umedwroc@gmail.com )}

Uniwersytet Medyczny im Piastow Slaskich we Wroclawiu https://orcid.org/0000-0002-1693-484X

\section{Malgorzata Malodobra-Mazur}

Uniwersytet Medyczny im Piastow Slaskich we Wroclawiu

\section{Karolina Cukierska}

Uniwersytet Medyczny im Piastow Slaskich we Wroclawiu

\section{Arleta Lebioda}

Uniwersytet Medyczny im Piastow Slaskich we Wroclawiu

\section{Anna Jonkisz}

Uniwersytet Medyczny im Piastow Slaskich we Wroclawiu

\section{Tadeusz Dobosz}

Uniwersytet Medyczny im Piastow Slaskich we Wroclawiu

\section{Robert Smigiel}

Uniwersytet Medyczny im Piastow Slaskich we Wroclawiu

\section{Research article}

Keywords: MTHFR, methylenetetrahydrofolate reductase, Down Syndrome, simple trisomy of chromosome 21, Single Nucleotide Polymorphism

Posted Date: September 24th, 2019

DOI: https://doi.org/10.21203/rs.2.14849/v1

License: (c) (i) This work is licensed under a Creative Commons Attribution 4.0 International License. Read Full License

Version of Record: A version of this preprint was published at Advances in Clinical and Experimental Medicine on February 19th, 2020. See the published version at https://doi.org/10.17219/acem/115078. 


\section{Abstract}

Background: Down Syndrome (DS) is the most frequent cause of intellectual disability. In $95 \%$ of cases, it is caused by simple trisomy of chromosome 21 resulting from nondisjunction of chromosomes in meiotic division. Currently, the molecular and cellular mechanisms responsible for the phenomenon of nondisjunction are unknown. In this paper, we evaluated the incidence of five single-nucleotide polymorphisms (SNPs) of the MTHFR gene in a population of Polish mothers who had given birth to children with trisomy 21 in comparison with a control group of women with healthy offspring. Methods: The test material comprised venous blood collected from mothers who had given birth to a child with Down syndrome (study group, $n=130$ ) as well as from women who had given birth to children without trisomy 21 (control group, $\mathrm{n}=88$ ). DNA was isolated using a kit manufactured by Qiagen. Amplification was carried out using a Qiagen Multiplex PCR Kit (Qiagen); genotyping was performed using SNaPshot Genotyping MasterMix (Applied Biosystems). Results: No statistically significant differences were observed in the frequency of genotypes between the examined groups in terms of the polymorphisms of the MTHFR gene. Conclusions: In the studied Polish population, no relationship was found between the occurrence of particular genotypes of the MTHFR gene, i.e. 677CT, 1298AC, rs3737964, rs4846048, and rs 1994798 , in women and the birth of children with trisomy 21 . The results contradict the validity of research on polymorphisms of the MTHFR gene as potential predisposing factors for the occurrence of trisomy 21 in children.

\section{Background}

Down syndrome (DS), known as trisomy 21 , occurs at an estimated frequency of about 1 in $650-700$ live births and is the most frequent known cause of intellectual disability. The chromosomal aberration associated with DS depends on the presence of an additional chromosome 21, which, in most cases $(95 \%)$, is caused by a simple trisomy resulting from the phenomenon of chromosome nondisjunction during meiotic division in the process of gametogenesis in one of the parents [1]. The additional chromosome 21 , in $90-95 \%$ of cases, is of maternal origin; the defective segregation of chromosomes occurs mainly during meiosis I ( $80 \%$ of cases), less frequently during meiosis II ( $20 \%$ of cases) [2-4].

Currently, the molecular and cellular mechanisms responsible for the phenomenon of nondisjunction are unknown, as are the potential factors which predispose to its occurrence. The only documented risk factor for giving birth to a child with trisomy 21 is the mother's age (when > 35 years) [4, 5]. In 1999, for the first time, studies were published in which it was suggested that polymorphisms within genes coding for enzymes indispensable in folate metabolism might constitute risk factors for chromosomal diseases, including DS [6].

The products of the metabolism of folates are indispensable compounds used in many cellular processes, primarily in the synthesis of nucleic acid precursors and the methylation of cellular components, mainly DNA. The folate cycle also enables the conversion of homocysteine to methionine. The key enzyme involved in this cycle is the enzyme methylenetetrahydrofolate reductase (MTHFR), 
which catalyzes the irreversible reduction of 5,10-methylenetetrahydrofolate (5,10-MTHF) to 5methylenetetrahydrofolate (5-MTHF), a methyl-group donor for homocysteine remethylation and methionine resynthesis. The end result, S-adenosylmethionine (SAM), the product of continued methionine conversion, is the basic compound required for the methylation of nucleic acids. DNA methylation plays a key role in gene expression as well as in cell differentiation. It has been proven that single nucleotide polymorphisms (SNPS) within the MTHFR gene cause a reduction in the activity of this enzyme, resulting in increased levels of homocysteine and in hypomethylation of nucleic acids $[1,5-6]$.

In vivo studies have demonstrated the influence of epigenetic phenomena, mainly DNA hypomethylation, on the occurrence of instability or incorrect segregation of chromosomes, or of aneuploidy $[7,8]$. In vitro studies on cell cultures (plant and animal) have confirmed that insufficient DNA methylation may result in chromosomal instability as well as nondisjunction and aberrations $[9,10]$. Similarly, a deficiency or lack of folates in the diet may affect the occurrence of DNA chain breaks and defective gene expression. Thus, researchers have reached the conclusion that folate deficiencies and abnormal expression of the MTHFR gene may pose a risk of chromosomal nondisjunction during meiosis, and, at the same time, increase the risk of trisomy 21 in children [1,5-7].

The polymorphisms of the SNP type within the MTHFR gene most often researched and described are rs1801133 (677CT) and rs1801131 (1298AC). The former is dependent on the transition of cytosine to thymine at position 677 in the 4th exon of the MTHFR gene. The result is the conversion of alanine to valine in the amino acid chain at position 222 of the protein. The enzyme variant coded in this way is thermolabile and is characterized by reduced activity [11-13]. The change in rs 1801131 occurs within exon 7 and consists of the transversion of adenine to cytosine at position 1298 of mRNA; instead of glutamine, alanine is incorporated at position 429 of the amino acid chain. The regulatory domain binding S-adenosylmethionine (SAM) undergoes modification, resulting in a reduction in the activity of MTHFR [12]. The authors of the study deemed it justified to take an interest in three other polymorphisms within the MTHFR gene: rs3737964, rs4846048, and rs1994798. The first, rs3737964, is located in the promoter region ( 5 ' near gene) of the MTHFR gene and consists of the conversion of guanine to adenine. Sequencing changes in this region may affect the expression of mRNA and the amount of protein (enzyme) produced. The flow of mRNA may also be influenced by the second polymorphism, rs4846048, which is located in the 3'UTR regulatory region and consists of the conversion of adenine to guanine. The last of the studied SNPs, rs1994798, is located within the intron and involves the exchange of cytosine for thymine. Polymorphisms located in introns are probably capable of modifying the expression of other genes or may be linked with other polymorphisms [14-16].

\section{Objectives}

The study presented here investigated the frequency of five SNP-type polymorphisms of the MTHFR gene, 677CT, 1298AC, rs3737964, rs4846048, and rs1994798, in mothers of children with trisomy 21 and in women giving birth to healthy children, with the aim of assessing the relationship between the variability of these polymorphisms and trisomy 21 in a Polish population. 


\section{Methods}

\subsection{Research material}

The study group consisted of 130 samples of venous blood collected with the use of EDTA from women who had given birth to a child with trisomy 21. Prior to the isolation of DNA, all samples were stored in a freezer at a temperature of $-80^{\circ} \mathrm{C}$. Approval no. KB20/2016 of the Bioethics Commission was granted for molecular tests, and collection of the material lasted from February 2016 to February 2017. All of the women involved expressed their informed consent for their participation in the study. The ages of women at the birth of children with DS ranged from 18 to 41 years, with a mean of 32 .

The control group consisted of 88 samples of isolated DNA, stored at $-20^{\circ} \mathrm{C}$ at the Molecular Techniques Unit of Wrocław Medical University. The DNA was collected in 2010-12, with approval no. KB-556/2008 of the Bioethics Commission. The samples were taken from women who had not given birth to children with trisomy 21 and who gave their informed consent for the use of their genetic material in molecular research. The ages of the women ranged from 25 to 78 years, with a mean of 52 .

\subsection{Genotyping}

In the case of the study group, first DNA was isolated, using the QIAamp DNA Mini Kit, from Qiagen, according to the manufacturer's instructions. The DNA thus isolated was stored at $-20^{\circ} \mathrm{C}$.

Genetic material was propagated in a multiplex amplification reaction using a Qiagen Multiplex PCR Plus Kit and specific primers in accordance with the manufacturer's instructions. The amplified fragments (5 $\mu \mathrm{L}$ ) were purified of unused deoxynucleotides and excess primers with $1.5 \mu \mathrm{L}$ of an digestion enzyme mixture: exonucleases I (Exonuclease I 2,7 U, Thermo Scientific) and alkaline phosphatases (FastAP Thermosensitive Alkaline Phosphatase, 1,4 U, Thermo Scientific), with digestion carried out for 60 minutes at $37^{\circ} \mathrm{C}$ and for 15 minutes at $80^{\circ} \mathrm{C}$ (for enzyme inactivation).

Detection of polymorphisms was performed by means of mini-sequencing using a SNaPshot Multiplex Kit (Applied Biosystems) in accordance with the manufacturer's instructions. Mini-sequencing primers were designed to hybridize to DNA directly at the changed polymorphic site. The sequencing reaction products were also purified of unused dideoxynucleotides using $0.5 \mu \mathrm{L}$ alkaline phosphatase (FastAP Thermosensitive Alkaline Phosphatase, $0,5 \mathrm{U}$, Thermo Scientific) for 30 minutes at $37^{\circ} \mathrm{C}$ and 15 minutes at $85^{\circ} \mathrm{C}$.

Detection of minisequencing reaction products was carried out by means of capillary electrophoresis in the presence of Hi-Di Formamide (Applied Biosystems) with the addition of $10 \mu \mathrm{L}$ of the internal standard GeneScan-120 LIZ Size Standard (Applied Biosystems). Prior to electrophoresis, the samples were denatured for 5 minutes at $95^{\circ} \mathrm{C}$; then the plate was cooled on ice for 3 minutes. Thus prepared, the plate was placed in a 3130 Genetic Analyzer sequencer (Applied Biosystems); analysis of the results was conducted using GeneMapper ID v3.2. 


\subsection{Methods of statistical elaboration}

Statistica v13.1 was used to elaborate the statistical results. Calculations of the frequency of individual genotypes as well as of the incidence of wild and mutant alleles in both studied polymorphic sites in the study and control groups were conducted using a chi-square test. This test was also used to calculate whether the distribution of genotypes obtained in the studied population deviated from the estimated distribution, based on the Hardy-Weinberg principle. A significance level of 0.05 was assumed.

\section{Results}

In the first stage of statistical analysis, the studied polymorphisms were checked in terms of maintenance of distributions of genotypes in the population consistent with the Hardy-Weinberg equilibrium (HWE). None of the polymorphisms deviated from HWE; for 677CT, $p=0.9986 ; 1298 \mathrm{AC}, p=0.9958$; rs3737967, $p$ $=0.9956 ;$ rs4846048, $p=0.9982 ; r s 1994798, p=0.9991$.

Based on the results of genotyping obtained for all 130 samples from the study group and 88 samples from the control group, the frequency of individual genotypes at both polymorphic sites was calculated.

In the case of $677 \mathrm{CT}$, the highest percentage in both groups was obtained for CT heterozygotes: $44.5 \%$ in the study group, $60 \%$ in the control group. The homozygous CC genotype constituted $40 \%$ in the study group and $32 \%$ in the control group, while homozygotes representing the TT mutation constituted 15.5\% and $8 \%$, respectively. Statistical analysis of the frequency of polymorphism in the studied groups showed no statistically significant differences $(p=0.0548)$. The frequency distribution is presented in Fig. 1 .

Polymorphism 1298AC was characterized by the following distribution of genotypes in the studied population: in the study group, the homozygous AA configuration accounted for $53 \%$, the heterozygous AC $37 \%$, and the homozygous CC $10 \%$, whereas, in the control group, these genotypes accounted for $38.5 \%, 51 \%$, and $10.5 \%$ of the population, respectively. In comparing the frequency of the occurrence of genotypes in the studied groups, no statistically significant differences were found according to the chisquare test $(p=0.0905)$. The distribution of genotypes for the 1298AC polymorphism is presented in Fig. 1.

At the site of rs3737964, the frequency of individual genotypes was as follows: the homozygous GG configuration constituted $55.5 \%$ in the study group and $40.5 \%$ in the control group; heterozygous GA, $35.5 \%$ and $49 \%$, respectively; and homozygous AA, $9 \%$ and $10.5 \%$. respectively. Comparison of these frequency distributions using the chi-square test showed no statistically significant differences $(p=$ 0.0986). These distributions are presented in Fig. 1.

At the polymorphic site of rs 4846048 , in both the study and control groups, the homozygous AA configuration constituted the largest percentage: $57 \%$ in the study group and $49 \%$ in the control group. AG heterozygotes were recorded at $35.5 \%$ and $40.5 \%$, respectively, mutant GG heterozygotes at $7.5 \%$ and 
$10.5 \%$, respectively. No statistically significant differences were indicated in the distribution of genotypes $(p=0.4790)$. The above data is presented in Fig. 1.

The following distribution of genotypes of the rs1994798 polymorphism was observed: for the homozygous CC configuration, $16 \%$ in the study group and $19.5 \%$ in the control group; for CT heterozygotes, $45.5 \%$ in the study group and $51.5 \%$ in the control group. In this case, as well, statistical analysis showed no statistically significant differences

$(p=0.3321)$. The frequency distribution is presented in Fig. 1.

Analysis of the frequency of mutant and wild alleles in the control and study groups also showed an absence of statistically significant differences in the cases of both studied polymorphisms $(p>0.05)$. Wild alleles (C) at $677 \mathrm{CT}$ accounted for $62.5 \%$ in the study group and $62 \%$ in the control group, whereas mutant alleles $(A)$ accounted for $37.7 \%$ and $38 \%$, respectively $(p=0.9552)$. Similarly, in the case of 1298AC, wild alleles (A) accounted for $71.5 \%$ in the study group and $64 \%$ in the control group, mutant alleles (C) for $28.5 \%$ in the study group and $36 \%$ in the control group $(p=0.2524)$. These frequencies are presented in Fig. 2.

\section{Discussion}

Trisomy 21, or Down syndrome, is a relatively common affliction, and the most widely known cause of intellectual disability, hence the investigation and determination of the molecular basis of this disease and the search for potential predisposing factors for its occurrence are justified. Simple trisomy, constituting $95 \%$ of cases, results from the phenomenon of nondisjunction which occurs during meiotic division; however, the mechanisms responsible for the abnormal segregation of chromosomes are still unknown [2].

In the search for the causes of faulty segregation of chromosomes, their instability, fragility, or aneuploidy, ever-greater attention is being drawn to the potential contribution of epigenetic phenomena, primarily DNA hypomethylation $[7,8]$. Deficiencies in dietary folate and disorders of the folate cycle which directly result in, inter alia, hyperhomocysteinaemia and insufficient synthesis of S-adenosylmethionine a fundamental donor of methyl groups necessary for DNA methylation - have been linked to the hypomethylation of nucleic acids. Disorders of the cyclic transformation of folate derivatives result primarily from a defect in the activity of the key enzyme in this cycle, i.e. methylenetetrahydrofolate reductase (MTHFR). Currently, more than 40 SNP polymorphisms have been described in the MTHFR gene; the direct influence of some of these on the reduction of the activity of the enzyme encoded by this gene, ultimately resulting in SAM deficiencies and DNA hypomethylation, has been proven $[1,5-7,11$, 17]. On this basis, a conclusion was drawn regarding the potential for linking nondisjunction, the reason for the vast majority of DS cases, with DNA hypomethylation, which can be brought about by disturbances of the folate cycle resulting from insufficient MTHFR activity, caused in turn by the occurrence of polymorphisms of single nucleotides within the associated gene. 
In this study, the two SNP polymorphisms most frequently associated with trisomy of chromosome 21 in MTHFR were taken into consideration, namely 677CT and 1298AC, as well as three others, not previously researched for the existence of correlations with DS, namely rs3737964, rs4846048, and rs1994798.

Observed differences between the study and control groups in the frequency of genotypes in 677CT and 1298 AC, as well as in all three remaining polymorphic sites, showed no statistical significance in the chisquare test

$(p>0.05)$. The distribution of the percentage of frequency of mutant and wild alleles in the studied SNPs also fell within the confidence interval in the chi-square test $(p>0.05)$; thus no statistically significant differences were observed in the studied groups in the Polish population.

The results presented in this paper are congruent with many other reports published in the relevant literature since the appearance of the first paper on this subject in 1999. This applies equally to studies of Caucasians and of other populations. Worth mentioning, inter alia, are studies on French (Chango et al., 2005) [18], Italian (Stuppia et al., 2002) [19], Danish (Kokotas et al., 2009) [20], and Croatian (Vraneković et al., 2010) [21] populations. In addition, analogous studies which also excluded the association of DS with the SNP polymorphisms 677CT and 1298AC were carried out in Jordan (Sadiq et al., 2011) [22], Romania (Bucerzan et al., 2017) [6], Brazil (Balarin et al., 2017) [5], Turkey (Boduroglu et al., 2004) [23], China (Jiajin et al., 2018) [1], and India (Kohli et al., 2008; Kaur et al., 2013; Mohanty et al., 2012) [24-26]. Confirmation was also obtained in an extensive meta-analysis by Yang et al. (2013), encompassing 32 articles excluding the association of MTHFR polymorphisms of 677CT and 1298AC with trisomy of chromosome 21 [27].

On the other hand, an equal number of researchers have proven a relationship between the occurrence of the described polymorphisms in the MTHFR gene in women and the birth of children with Down syndrome. This is evidenced by the first study by James et al. (1999) on an American population [7]. Similar results were obtained by Cyrus et al. (2009, southern India) [28], Coppedè et al. (2009, Italy) [29], Meguid et al. (2008, Egypt) [30], and da Silva et al. (2005, Brazil) [31]. Mention may also be made of meta-analyses conducted by Wu et al. (2012) [32], Rai et al. (2014) [33], and Victorino et al. (2014) [34].

The glaring discrepancy between these reports renders any inferences about single nucleotide polymorphisms $677 \mathrm{CT}$ and $1298 \mathrm{AC}$ as potential predisposing factors for the occurrence of DS in children doubtful and controversial, at the very least. The present paper also indicates the absence of any connection between the other three polymorphisms (rs3737964, rs4846048, and rs1994798) and the occurrence of DS. All of the above-mentioned authors emphasize that these discrepancies exclude SNPs in the MTHFR gene as an independent risk factor for trisomy 21 . The polymorphisms in question may nevertheless constitute one of many factors, including additional genetic, epigenetic, environmental, and other random factors, whose simultaneous interaction may result in a predisposition to the birth of a child with trisomy 21[57]. 
The results of the present study of a Polish population do not contradict the reports published to date. It is not out of the question that larger sample size (in both the test and control groups) would result in statistically significant differences between the frequencies of individual genotypes of 677CT and $1298 \mathrm{AC}$ in the studied groups, given that the results of statistical analysis in some comparisons were close to decisive values. However, neither does the exclusion of a relationship between these polymorphisms in the MTHFR gene in mothers and the birth of children with trisomy 21 in this Polish population equate to the lack of participation of the described changes in the molecular basis of DS. The most appropriate direction of research appears to be an investigation of the simultaneous influence of several factors in the pathomechanism of DS; this would require additional, extremely detailed analyses.

\section{Conclusions}

In the present paper, no correlation was observed between the occurrence of polymorphisms in the MTHFR gene in mothers and the birth of children with Down syndrome in a Polish population. The results contradict the validity of research on the 677CT and 1298AC (as well as rs3737964, rs4846048, and rs1994798) polymorphisms of the MTHFR gene as potential predisposing factors for the occurrence of trisomy 21 in children.

\section{Declarations}

\section{Ethics Approval and Consent to Participate:}

Research was conducted with approval no KB20/2016 and KB-556/2008 of the Ethics Committee at the Medical University in Wroclaw.

All of the women involved expressed their informed consent for their participation in the study by signing proper form.

\section{Consent for publication:}

Not Applicable.

Competing interests:

Competing interest not declared.

\section{Funding:}


This research was conducted using statutory resources of Wrocław Medical University: Maintenance of research potential, task number ST.A122.17.039.

Authors declare no conflict of interest.

The datasets used and/or analysed during the current study available from the corresponding author on reasonable request..

Author's contribution:

PC - genotyping of study group, writing the manuscript

KC - genotyping of control group

MMM, AJ - genotyping assay optimization

AL - DNA extraction

MMM - control group collection, edition and revision of manuscript

TD - conceptual work

RS - study group collection, contact with patients

All authors have read and approved the manuscript

\section{Acknowledgements:}

Not Applicable.

\section{References}

1. 1. Jiajin L., Shuyan C., Junxiao C., Xiudi W.: Genetic polymorphisms in folate metabolism as risk for Down syndrome in the southern The Journal of Maternal-Fetal \& Neonatal Medicine [serial online] 
2018, 1:6.

2. 2. Tobias E. S., Connor M., Ferguson-Smith M.: Wrodzone wady rozwojowe.

W: Genetyka medyczna. Wydanie III polskie (red.: Latos-Bieleńska A.), Wyd. PZWL, Warszawa, 2014,

3. 3. Ferenc T., Bratkowska W., Pacholczyk M., Jakubowski L.: Zespoły aberracji chromosomowych. W:

Ferenc T., Drewa G.: Genetyka medyczna. Podręcznik

dla studentów. Wyd. Elsevier Urban \& Partner, Wrocław, 2011, 479-481.

4. 4. Maitra A.: Choroby uwarunkowane genetycznie i choroby wieku dziecięcego.

W: Kumar V., Abbas A. K., Aster J. C.: Robbins. Wydanie II polskie

(red. Olszewski W.), Wyd. Edra Urban \& Partner, Wrocław, 2017, 259-260.

5. Balarin M., Cintra M., Cordeiro F., Naves L., Silva-Grecco R.: Screening of six polymorphisms related with folate metabolizm in parents of individuals with Down syndrome. The Journal of Maternal-Fetal \& Neonatal Medicine [serial online] 2017,

1-191.

6. Bucerzan S., Popp R.A., Vlad R.M., Lazea C., Nicolaescu R., Grigorescu-Sido P.: Evaluation of C677T and A1298C polymorphism of the methylenetetrahydrofolate reductase gene as a maternal risk factor for trisomy 21. Revista Romana de Medicina de Laborator [serial online] 2017, 25:1.

7. 7. James S. J., Gaylor D. W. i: Abnormal folate metabolizm and mutation in the methylenetetrahydrofolate reductase gene may be maternal risk factors for Down syndrome. Am J Clin Nutr [serial online] 1999, 70: 495-501.

8. 8. Guang-zhi, Grundy P. E., Narayan A., Ehrlich M.: Frequent hypomethylation in Wilms tumors of pericentromeric DNA in chromosomes 1 and 16. Cancer Genet Cytogenet [serial online] 1999, 109:34-39.

9. 9. Harrison J. J., Anisowicz A., Gadi I. K., Raffeld M., Sager R.: Azacytidine-induced tumorigenesis of CHEF/18 cells: correlated DNA methylation and chromosome changes. Proc. Natl. Acad. Sci. [serial online] 1983, 80: 6606-6610.

10. 10. Lengauer C., Kinzler K. W., Vogelstein B.: DNA methylation and genetic instability in cororectal cancer cells. Proc. Natl. Acad. Sci. [serial online] 1997, 94:2545-2550.

11. 11. Kurzawińska G., Seremak-Mrozikiewicz A., Drews K., Barlik M., Mrozikiewicz P. M.: Genetic conditioned changes in activity of 5,10-methylenetetrahydrofolate reductase (MTHFR) and recurrent miscarriages. Ginekol Pol. [serial online] 2009, 80:762-767.

12. 12. Seremak-Mrozikiewicz A.: The significance of folate metabolism in complications of pregnant women. Ginekol Pol. [serial online] 2013, 84:377-384.

13. 13. Internetowa baza danych SNP SNPedia, http://www.snpedia.com/index.php/SNPedia

14. 14. Baza danych SNP National Center for Biotechnology Information, http://www.ncbi.nlm.nih.gov/snp/

15. 15. Xiaogang L., Lan-Juan Z., Yong-Jun L., Dong-Hai X., Recker R. R., Hong-Wen D.: The MTHFR gene polymorphism is assiociated with lean body mass but not fat body mass. Hum Genet [serial online] 2008, 123: 189-196. 
16. 16. Janusz P.: Polimorfizmy genów receptorów estrogenowych u chorych z postacią progresywną i nieprogresywną skoliozy idiopatycznej, rozprawa doktorska, Uniwersytet Medyczny im. Karola Marcinkowskiego w Poznaniu, 2014.

17. 17. Magnowski P., Seremak-Mrozikiewicz A., Nowak-Markwitz, Kurzawińska G., Drews K., Spaczyński M.: No assiociaton between MTHFR 677C>T polymorphism

and oviarian cancer risk in BRCA1 mutation carries in Wielkopolska region. Ginekol Pol. [serial online] 2010, 81:506-510.

18. 18. Chango A., Fillon-Emery N., Mircher C., Blehaut H., Lambert D., Herbeth H., James S., RethoreO., Nicolas J.P.: No association between common polymorphisms in genes of folate and homocysteine metabolism and the risk of Down's syndrome among French mothers. Brit J Nutr [serial online] 2005, 94:166-169.

19. 19. Stuppia L., Gatta V., Gaspari A.R., Antonucci I., Morizio E., Calabrese G., Palka G.: C677T mutation in the 5,10-MTHFR gene and risk of Down syndrome in Italy.

Eur J Hum Genet [serial online] 2002, 10:388-390.

20. 20. Kokotas H., Grigoriadou M., Mikkelsen M., Giannoulia-Karantana A., Petersen M.B.: Investigating the impact of Down syndrome related common MTHFR 677C>T polymorphism in the Danish population. Dis Markers [serial online] 2009, 27:279-285.

21. 21. Vranekovic J., Babic Bozowic I., Starcevic Clzmarevic N., Buretic-Tomljanovic A., Ristic S., Petrovic O., Kapovic M., Brajenovic-Milic B.: Functional interferencje of methelenetetrahydrofolate reductase gene polymorphisms on enzyme stability as a potential risk of Down syndrome in Croatia. Dis Markers [serial online] 2010, 28:293-298.

22. 22. Sadiq M.F., Al.-Refai E.A., Al.-Nasser A., Khassawneh M., Al.-Batayneh Q.:

Methylenetetrahydrofolate reductase polymorphisms C677T and A1298C as maternal risk factors for Down syndrome in Jordan. Genet Test Mol Bioma [serial online] 2011, 15:51-57.

23. 23. Boduroglu K., Alanay Y., Koldan B., Tuncbilek E.: Methylenetetrahydrofolate reductase enzyme polymorphisms as maternal risk for Down syndrome among Turkish women. Am J Med. Genet [serial online] 2004, 127A:5,10.

24. 24. Kohli U., Arora S., Kabra M., Ramakrishnan L., Gulati S., Pandey R.M.: Prevalence of MTHFR C677T polymorphism in north Indian mothers having babes with trisomy 21 Down syndrome. Down syndrome research and practice [serial online] 2008, 12:133-137.

25. 25. Kaur A., Kaur A.: Prevalence of methylenetetrahydrofolate reductase 677 C-T polymorphism among mothers of Down syndrome children. Indian Journal of Human Genetics [serial online] 2013, 19: $412-414$.

26. 26. Mohanty P.K., Kapoor S., Dubey A.P., Pandey S., Shah R., Nayak H.K., Polipalli S.K.: Evaluation of C677T polymorphism in methylenetetrahydrofolate reductase gene and its association with levels of serum homocysteine, folate, and vitamin $B_{12}$ 
as maternal risk of Down syndrome. Indian Journal of Human Genetics [serial online] 2012, 18: 285289.

27. 27. Yang M., Gong T., Lin X., Qi L., Guo Y., Cao Z., Shen M., Du Y.: Maternal gene polymorphisms involved in folate metabolism and the risk of having a Down syndrome offspring: a meta-analysis. Mutagenesis [serial online] 2013, 28:661-671.

28. 28. Cyril C., Rai P., Chandra N., GiponathM., Satyamoorthy K.: MTHFR gene variants C677T, A1298C and association with Down syndrome: a case-control study from South India. Indian Journal of Human Genetics [serial online] 2009, 15:61-64.

29. 29. Coppede F.: The complex relationship between folate/homocysteine metabolism and risk of Down syndrome. Mutat Res [serial online] 2009, 682:54-70.

30. 30. Meguid N.A, Dardir A., Khass M., El Hossieny L., Ezzat A., El Awady M.K.: MTHFR genetic polymorphism as risk factor in Egyptian mothers with Down syndrome children. Dis Markers [serial online] 2008, 24: 19-26.

31. 31. da Silva L.R.J., Vargani, de Camargo Galdieri L., Porto M.P.R., Longhitano S.B., Brunoni D., D'Almeida V., Perez A.B.A.: Relationship between polymorphisms in genes involved in homocysteine metabolism and maternal risk for Down syndrome in Brazil. Am J Med Genet [serial online] 2005, 135A: 263-267.

32. 32. Wu X., Wang X., Chan Y., Jia S., Luo Y., Tang W.: Folate metabolism gene polymorphisms MTHFR C677T and A1298C and risk for Down syndrome offspring:

a meta-analysis. Eur J Obstet Gyn R B [serial online] 2013, 167: 154-159.

33. 33. Rai V., Yadav U., Kumar P., Yadav S.K., Mishra O.P.: Maternal methylenetetrahydrofolate reductase C677T polymorphism and Down syndrome risk: a meta-analysis from 34 studies. Plos One [serial online] 2014, 9: 1-15.

34. 34. Victorino D.B., Godoy M.F., Goloni-Bertollo E.M., Pavarino E.C.: Meta-analysis

of methylenetetrahydrofolate reductase maternal gene in Down syndrome: increased susceptibility in woman carriers of the MTHFR 677T allele. Mol Biol Rep [serial online] 2014, 41

\section{Figures}


A

a Study group $\mathbf{n}$ Control group

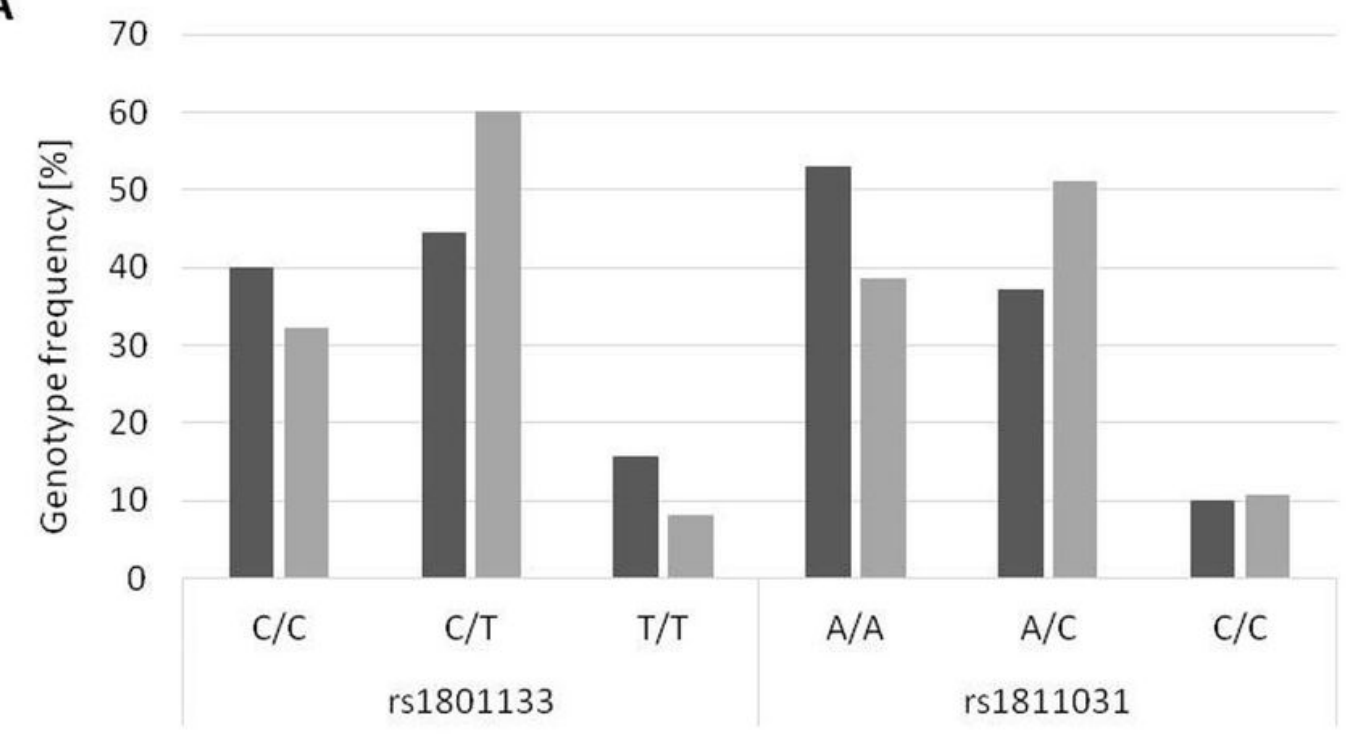

B

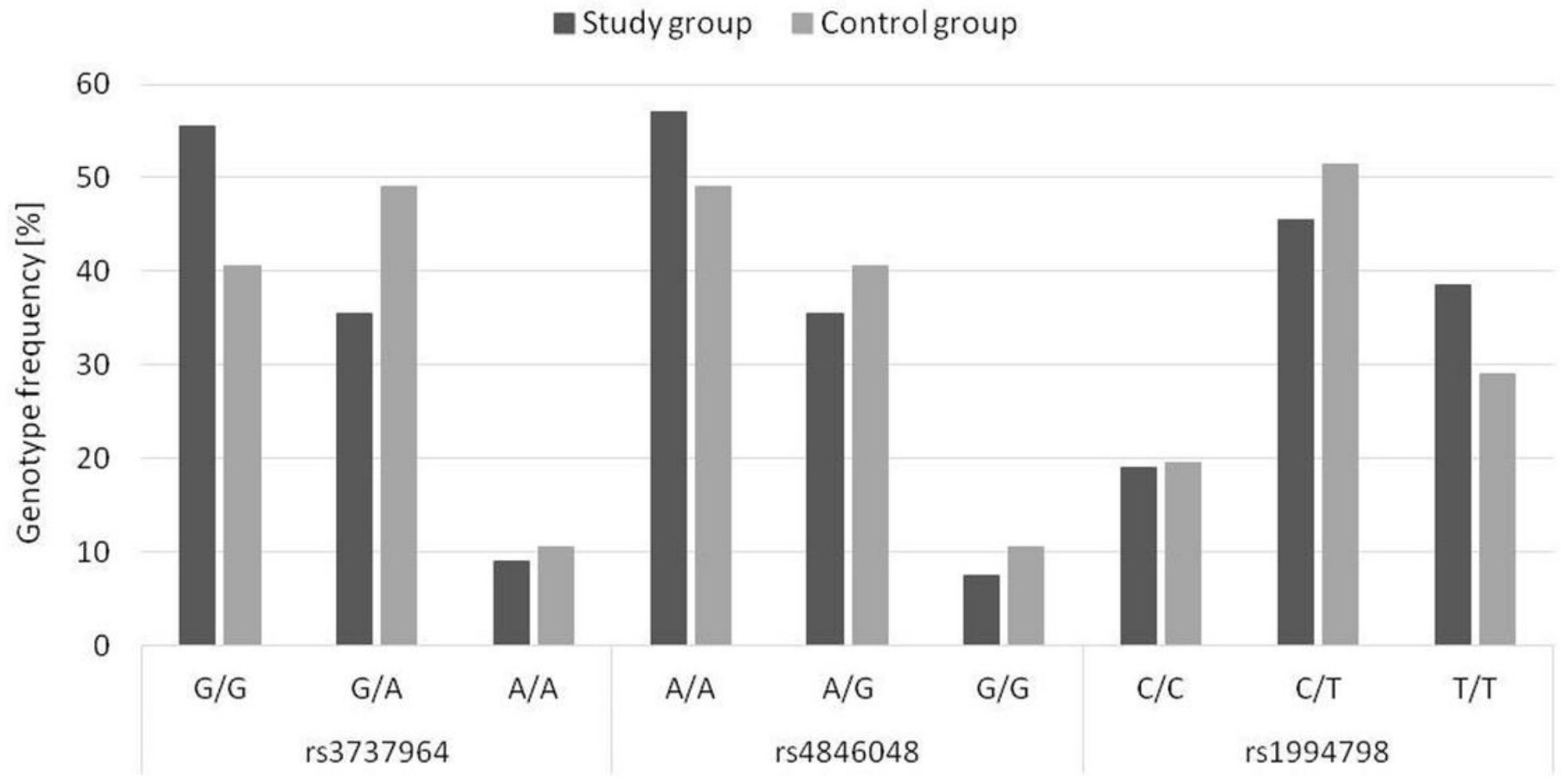

Figure 1

Genotypes frequencies of investigated SNPs in MTHFR gene in study group compared to control group. A - SNPs located in exons; B - SNP located outside exons, in various functional region of MTHFR gene. 


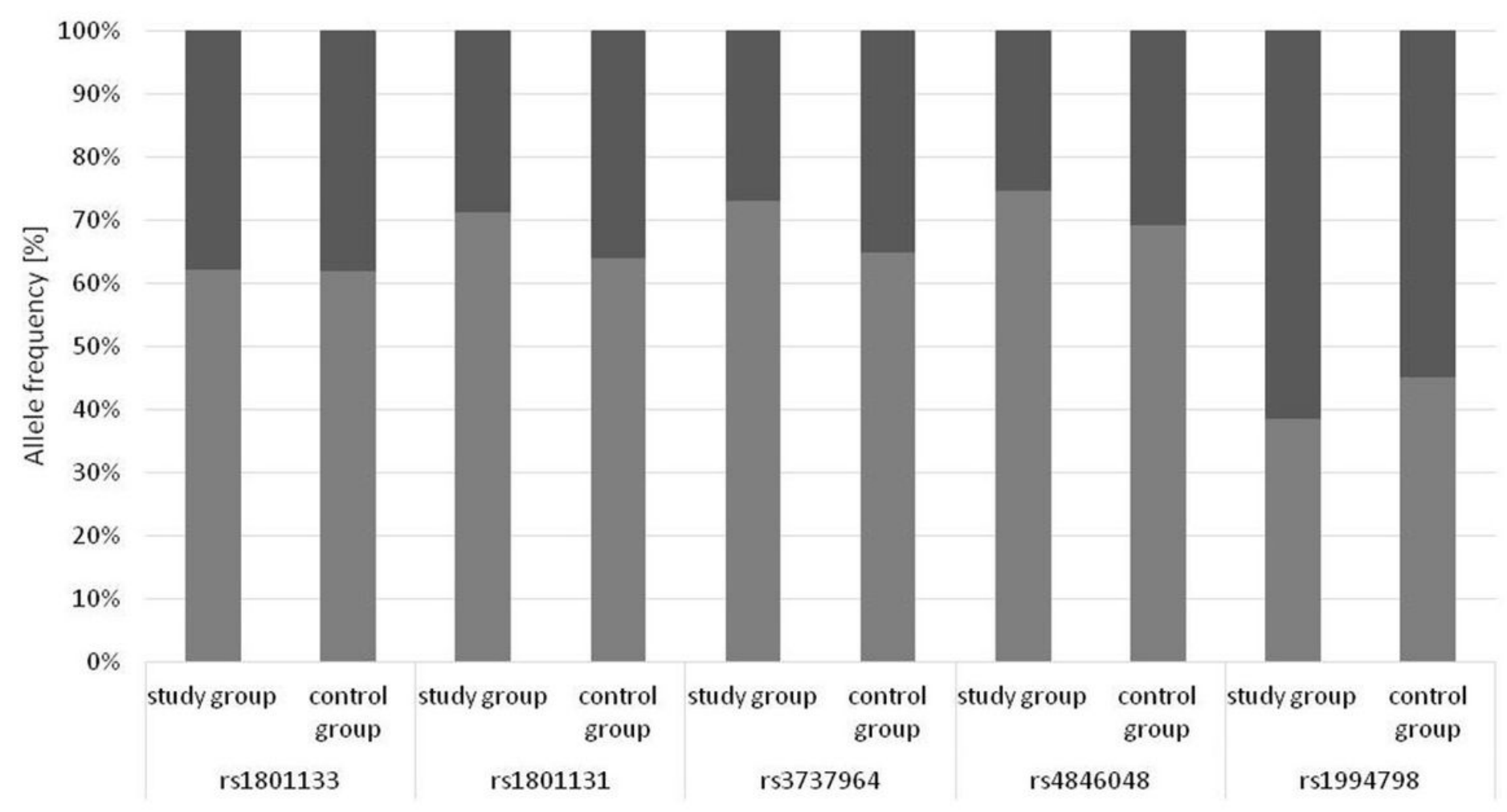

\section{Figure 2}

Frequency of mutant alleles and wild-type alleles in 677CT and 1298AC, as well as rs3737964, rs4846048, and rs 1994798, in the study and control groups. The results indicated no statistically significant differences ( $p>0.05$ in all cases). 